研究発表論文

\title{
江戸時代の大坂の石屋
}

\section{Study on Stonemasons at Osaka in the Edo Period}

飛田 範夫*

Norio HIDA

摘要 : 江戸時代の庭園に使われている庭石の販売経路，燈籠・踣踞などの石造品の製作と販売経路に ついては, 不明な点が多い。大坂について史料を調べてみると、石材の運搬に便利なように西横堀と 長堀, 東横堀（松屋町筋）の堀割り沿いに, 多くの石屋が分布していたことがわかる。庭石は各地の 名石, 石材としては御影石・竜山石・和泉石などが搬入され，原石あるいは加工品が再び各地に販売 されている。高野山などに残存する石造品の刻銘からも，大坂の石屋の活動を知ることができる。賃 金・労働時間・販売などについても問題は多かったが，既得の権利を守るために明和 7 年（1770）に は，石問屋株仲間と切石屋株仲間が形成されている。

1.はじめに

江戸時代の庭園にはさまざまな庭石が使われ，燈籠や醮踞など 多くの石造品が置かれている。これらの庭石の入手や石造品の製 作・販売などがどのようにされていたのかを，大坂について考察 したい。

これまでの大坂の石屋についての研究としては, 奇多楼主人 (本名不詳) の「徳川期に於ける大坂の石屋」がある11。昭和初 期に大阪近辺の神社を巡って，鳥居や燈籠に刻まれている銘文か ら, 江戸時代の大坂の石屋の名前之所在地を明らかにしている。 江戸時代の石屋の同業者組合である株仲間については，石問屋と 切石屋が存在していたことが，大阪市編纂・発行の『大阪市史 （第1・第 2)』（大正 2 年 [1913]）に述べられている。

しかし，江戸時代の石屋の所在地や名前については，文献史料 からの考察はまだされていない。燈籠や蹲踞の原石の産地，製作 した石工の労働状況，販売経路などについても不明な点が多い。

当時，一般に流布していた大坂の案内書からは，石屋の名前之 所在地, 石材の産地, 石造品の種類などを知ることができる。ま た，大阪市参事会編纂・発行『大阪市史（第 3 第 5 )』(明治 44 年 [1911]）には，江户時代の膨大な史料が収められていて，石 問屋や石工についても多くの史料が含まれている。これらの史料 を基に, 大坂の石屋の名前之所在地, 石材の購入方法, 仕事の内 容, 労働条件, 販売経路などについて, 詳細を見ていくことにし たい。

\section{2. 大坂の石屋の所在地}

水雲子著『懐中難波雀』（延宝 7 年 [1679]）の「九十六，諸商 人諸職人売物所付」の「い」の項に ${ }^{2)}$,

石之類 西横堀，同 松屋町筋，同 長堀四つはし，同 天 神橋石屋之浜

とあるから，江戸時代前期の大坂の石屋はこれらの場所に集まっ ていたと考えられる。延享版（1744～1748）『改正増補 難波丸 綱目』の「諸職商人取付いろは分」の「い」項には ${ }^{32}$,

石工 西よこほり・長ほり

石屋 西よこほり・長ほり

石巨 西横ほり・京町堀より北，阿わさほり（阿波座堀）よ り南へ

上書かれている。西横堀と長堀には多くの石工が居住し, 石屋屯
軒数が多かったことがわかる。石臼について別個に書いているの は，石造品の中でも特殊なものだったからだろう。

これに対して奇多楼氏は石屋の所在地の主だった所として, 長 堀十町目（佐野屋橋南詰め）俗称石屋浜 [現，中央区西心斎橋］・ 西横堀箱橋西詰め権右衛門町［西区阿波座］・伏見堀［西区京町 堀・䩲本町］・立売堀 [西区立売堀・新町］・松屋町九／助橋 [中央区松屋町] - 炭屋町 [西区北堀江・南堀江］・阿波座日向 町 [西区立売堀] などを挙げ，その他に西堀 [西区南堀江］・北 堀江二町目 [西区北堀江］・上町 [東区］・新川 [浪速区? ］・ 下寺町源正寺坂 [天王寺区］などがあるとしている [表 1 ]。

大坂の石屋の分布については, 『懐中難波雀』と奇多楼氏は相 違しているように見えるのだが, 『懐中難波雀』は堀割りに従っ て区分していると考えられる [図 1]。『懐中難波雀』の「西横堀 は, 奇多楼氏が言う西横堀笹橋之炭屋町を合わせたものであり, 「長堀四つはし」というのは，長堀十町目が中心になっていたと いうことなのだろう。「松屋町筋」は現在も残る東横堀に沿った 所だが, 松屋町の九ノ助橋の近辺に石屋が多かったと解釈できる。 奇多楼氏が指摘するように「運輸の便よき市内川々の浜辺に散 在した」のが大坂の特色だが, 特に西横堀・長堀・東横堀に沿っ て多くの石屋が存在していたということになる。南側の道頓堀に 石屋がなかったのは，芝居小屋が建ち並ぶ繁華街だったため之考 えられる。

\section{3. 各場所の石屋の状況}

\section{(1) 西横堀の石屋}

堀割りに従って，それぞれの場所の石屋の特色を見ていくこと にしたい。大坂市中を南北に流れていた西横煀川は，昭和 39 年 （1964）から 46 年にかけて埋め立てられ，さらに阪神高速大阪環 状線（高架）が建設されて昔の面影はない。

江戸時代前期（17 世紀）の大坂の石屋については，『人倫訓蒙 萝彙（巻 3)」(元禄 3 年 [1690]) の「宕伐」の項に「大坂は横 堀にあり」と記され，同書（巻 4 ）の「庭石や」の項には「海山 の石, 等石, 石船, 井筒, 宕樋, 手水鉢等」を扱うとあり, 「大 坂は横堀にあり」と書かれている。

この「横堀」というのは，江戸時代初期に開削されたとされる 西横堀川のことを指している。燈籠や蹲踞などの細工仕事をする 石切屋（切石屋とも呼ぶ）や，庭石や玉砂利を販売する庭石屋は，

*修成建設専門学校・緑の学科 
表-1 石造品調査から判明している大坂の石屋 （奇多楼主人「徳川期に於ける大坂の石屋」による）

\begin{tabular}{|c|c|}
\hline 所在地 & 年 代 - 氏 \\
\hline 長 堀 & 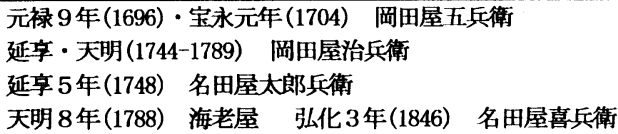 \\
\hline 西横堀 & $\begin{array}{l}\text { 延享(1744-1748) 尚玉沢町伊予屋又兵衛 } \\
\text { 寛政・弘化・安政(1789-1860) 権右衛門町和泉屋四郎兵衛 } \\
\text { 天保(1830-1844) 相生橋泉宇・尚玉沢町伊予屋市兵衛・ } \\
\text { 篭屋町泉安 }\end{array}$ \\
\hline 伏見堀 & $\begin{array}{l}\text { 宝暦(1751-1764) 石屋町三郎兵衛 } \\
\text { 延享・宝暦・安永 (1744-1781) 和泉屋仁右衛門 }\end{array}$ \\
\hline 立売堀 & $\begin{array}{ll}\text { 天和 (1681-1684) } & \text { 難波屋九左衛門 } \\
\text { 貞享 3年(1686) } & \text { 九兵衛 }\end{array}$ \\
\hline 松屋町 & $\begin{array}{l}\text { 享保(1716-1736) } \\
\text { 明泉定 } \\
\text { 寛政(1789-1801) } \\
\text { 文政(1818-1830) 和田屋由兵衛 } \\
\text { 天保(1830-1844) }\end{array}$ \\
\hline 炭屋町 & 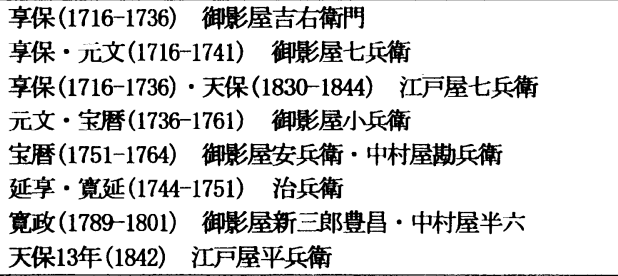 \\
\hline 西 堀 & 寛政·文化(1789-1818) 西川屋五郎兵衛 \\
\hline 北蜀江 & 寛政(1789-1801) 吹田屋喜八 \\
\hline 上 町 & $\begin{array}{ll}\text { 宝暦(1751-1764) } & \text { 大和屋二郎兵衛 } \\
\text { 天明(1781-1789) } & \text { 吉島六兵衛 }\end{array}$ \\
\hline 新 川 & 安政(1854-1860) \\
\hline 下寺町 & 源正寺坂御影屋新六 \\
\hline
\end{tabular}

江戸時代前期には西横堀周辺にまとまって存在していたと考えら れる。この地域に石屋が多かったのは，木津川・安治川の河口に 近いことから石材の運搬に便利で, 背後に作業や石造品の展示・ 保管のための広い土地を確保できたからではないだろうか。

秋里離島著『摄津名所图絵（巻 4)』（寛政 6 年 [1794]）にも 「西横堀の北は熹声物問屋・石工多し」とあり，江戸中期にも繁 栄していたことが同える。江戸前期と同様に，ここには庭石屋や 手水鉢などの石造品を製作する石屋が多かったのだろう。しかし， 『懐中難波雀』（延宝 7 年 [1679]）の「九十六，諸商人諸職人売 物所付」の「世」の項に，「石塔屋 西上こほり」と書かれてい るから，五輪塔などの墓石を作る店む存在していたことになる。

具体的な店の名と店主については，『懐中難波雀』の「三十六， 御用聞町人」の項に, 「石屋西上こほり 本庄屋庄兵衛」とあ り，18 世紀中頃の『改正増補 難波丸綱目』の「三郷御公用町 人衆」の項に,「石屋 平の町西上こほり 石屋孫兵衛」とある。 また，『浪華買物独案内』（天保 3 年 [1832]）には5

諸石所 権右衛門町 樋口屋加右衛門

諸石所 西横堀汃や町 岡田屋五兵衛

神社仏閣石細工所上細工人 権右衛門町 いづみ屋仁右衛門 神社仏閣石細工所 西横堀新渡辺橋西詰 小嶋屋半兵衛 之記されている。権右衛門町は東本願寺裏側の西横堀の西岸一帯 で，新渡辺橋はそこに架かっていたものだった。

西横堀の石屋のもう 1 つの中心だった四ッ橋近くの炭屋町につ いては, 『浪華買物独案内』に「神社仏閣石細工所 西横堀炭屋 町御影屋新三郎」之記載されている。寛政年間（1789～1801） の「御影屋新三郎豊昌」について, 奇多楼氏は「姓を飯田氏と称 し，金屋橋東詰に住した。（後継者は）一時住吉大社の専属とな

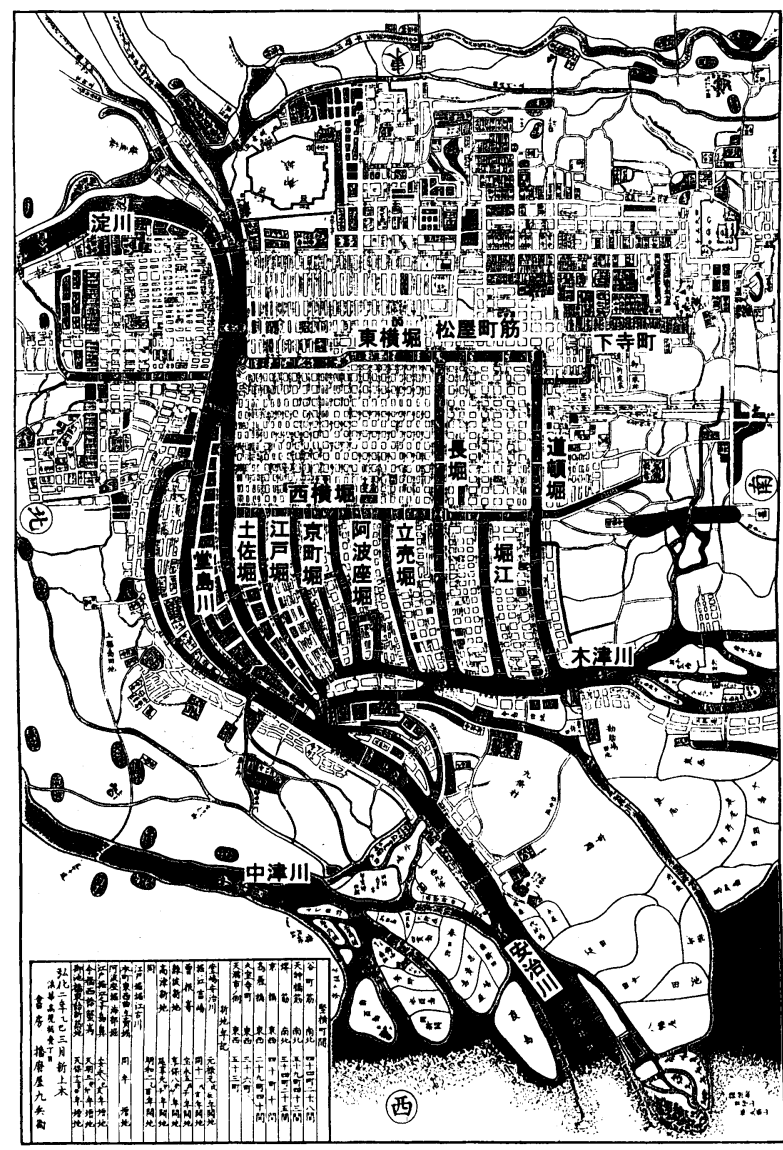

図-1 大坂の堀割り（原図, 弘化 2 年 [1845]）

り業況盛大であつたが，明治年間廃業した」としている。 (2) 長堀の石屋

大坂の市中を東西に貫いていた長堀は，昭和 38 年（1963）か ら 48 年にかけて埋め立てられて, 現在は長堀通（国道 308 号線） になっている。ここも都市化が進み, 道路の両側にはビルが建ち 亚び，江戸時代の面影は残っていない。

前掲の『摄津名所図会（巻 4)』には，江戸時代中期に長堀の 石屋が繁昌していた状況を描いた絵図が掲載されている[図2］。 この時期には西横堀よりも長堀の石屋の方が，繁栄するようになっ たのだろうか。図には石屋の店先の様子やたくさんの原石, 燈籠 や巨大な庭石, 船から轆轤を使って庭石を陸揚げしようとしてい る人びとの姿が描写されている。この図の中の説明文には,

長堀の石浜は山海の名石, あるは御影石・立山・和泉石など 諸国の名産をあつめ, 其好に従ふて石の鳥居・不の駒犬。燈 爐・水鉢・石臼・地蔵・大日・不動・阿弥陀・宕碑・道標

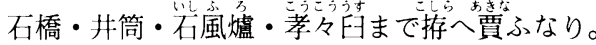
と述べられている。

各地から運ばれてきた石を加工して，社寺用あるいは日常用の さまざまな石造品を作っていたことがわかる。罒にも店先で燈籠・ 仏像などを彫っている石工の姿が描かれている。石造品の刻銘調 査からは, 長堀の石屋が三津八幡社の水盤, 住吉神社の燈籠, 天 満神社の狛犬, 大江神社の石鳥居などを製作していたことが知ら れているが，この『図会』の絵図や記述とも合致している。

長堀の石屋の店主と所在地については，江戸時代後期の『浪華 買物独案内』に,

諸石所 長堀心斎橋西へ入 灘屋太郎兵衛

諸石所 長堀心斎橋西入入 井筒屋善五郎

諸石所 長堀十丁目江戸屋七兵衛 


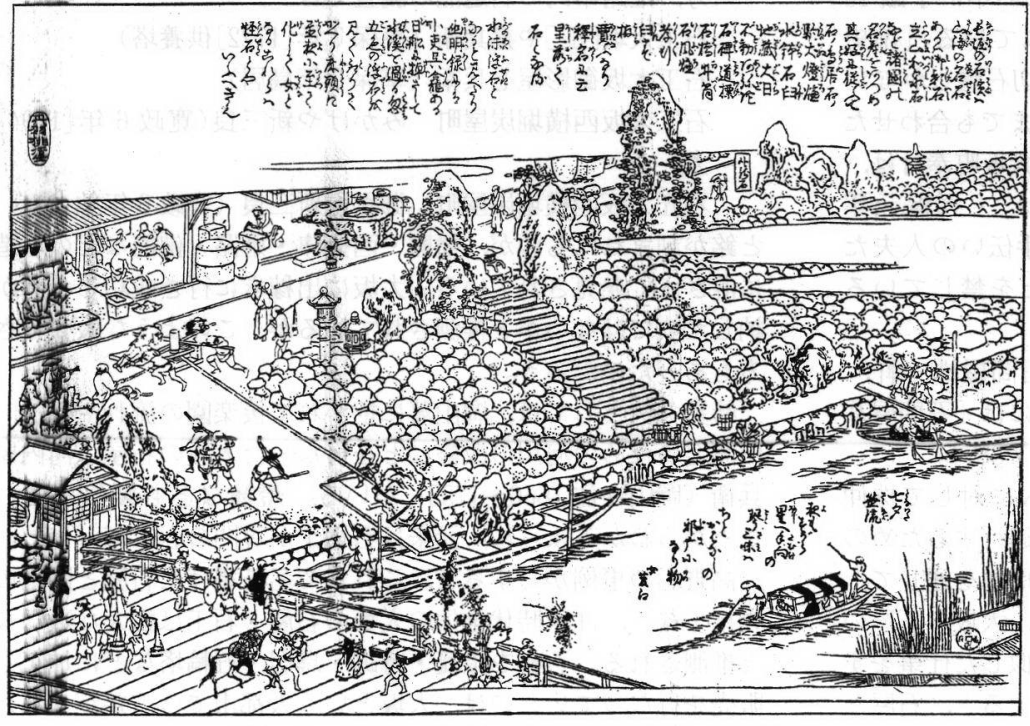

図-2 長堀の石屋（『摂津名所図会（巻 4)』）

これらの庭石や石材を各石屋が直接購入し ていたのではなく, 間には石問屋が介在して いた。木津川・安治川の川口十番の水尾杭に 入港する石を, 石問屋は現金ですべて引き取 り，これを７軒の石屋と希望者に売り渡し， 代金 10 多につき口利き料として 7 分 (7\%) を取っている。石屋から直接に産地に注文さ れたむのについては，荷が入港した時に問屋 がその送り状と現品を照合して相違がないか を確認し, 石屋に引き渡すという取り決めに なっていた（前掲『大阪市史(第 1)』1109 頁。以下 [市史 1 -1109] と略す)。

堀割り内での石の運搬については，寛永 20 年（1643）から「石船」が活躍している。 大石船と呼ばれたものは, 長さ 9 間 4 尺（5 尺を 1 間として測っているので， 1 尺を 30 $\mathrm{cm}$ とすると $14.7 \mathrm{~m})$ ，幅は 1 間 3 尺 5 寸 (2.6m) で, 船頭が 3 人乗っていた。小石船 は長さ 8 間 2 尺 $(12.6 \mathrm{~m})$, 幅は 1 間 2 尺 5 寸 $(2.3 \mathrm{~m})$ で，船頭は 1 人となっていた

と記されている。

\section{（3）松屋町筋 (東横堀) の石屋}

文禄 3 年（1594）に豊臣秀吉によって開削されたという東横堀 は, 現在む残っている。堀の東側に位置する松屋町筋には, 古く からの人形・花火・飲食などの店が建ち並んでいるが，石材店は 見当たらない。

天保 3 年（1832）の『浪華買物独案内』に, 石屋として「安堂 寺橋西詰 諸石所 堺屋佐右衛門」と書かれている。江戸時代前 期の『惟中難波雀』の「九十六, 諸商人諸職人売物所付」の「世 の項に，「同（石塔屋） 松屋町筋」とあることからすると，当 初は墓右を作る店が多かったと考えられる。

秀吉が大坂の城下町を築いた時に石工を集めたはずだが，彼ら が当時居住していた場所は, 秀吉が開削した東横堀の周辺だった 可能性はある。

\section{（4）その他の場所の石屋}

『懐中難波雀』が挙げている「天神橋石屋之浜」は，『大坂壾鑑 集成』（宝暦 6 年 [1756]）に「いし屋浜 天神橋南詰より東」と あるから，現在の中央区石町辺りになる。石町という町名は「国 府」が訛って「こくまち」になったとされているので，石屋之は まったく関連がない。ここの石屋についての具体的な史料は見当 たらない。

立壳垝は西横堀から木津川まで東西に掘削された堀割りだが, 昭和 31 年（1956）に埋め立てられている。この地域の石屋につ いては『浪花袖鑑』(享保 13 年 [1728]) の「御継飛脚」の項に, 「石切 立売堀 孫兵衛」之記されている ${ }^{6)}$ 。

\section{4. 石尿の仕事状況}

\section{(1) 石材の仕入れ}

大坂の石屋はどこから石材を仕入れていたのだろうか。前にふ れた『揕津名所図会（巻 4)」(寛政 6 年 [1794]）の図中の説明 文によると，長堀には庭石としては各地の名石，石造品や建築用 などの石材としては摂津 (兵庫県神戸市御影付近) 産の御影石 (花崗岩), 備前 (兵庫県高砂市伊保町付近) 産の竜山石 (流紋岩 質凝灰岩), 和泉 (大阪府阪南市付近) 産の和泉石（砂岩）など が，船で運ばれて来ている。同書の西横堀の石屋の項に「大坂石 は御影山の名石なり」と書かれていることからすると, 当時は御 影石が大量に入っていて，大坂で販売していたことから，大坂石 と呼ばれていたことがわかる。
[市史 $1-337 \cdot 338]$ 。

\section{（2）石工の労働状況}

石造品を製作していた石工（石切）の労働時間については，寛 政 6 年（1794）11月 23 日に石切屋などに, 次のような口達が出 されている[市史 4-201]。

朝六ッ時（午前 6 時）より五ツ時（午前 8 時）迄の内㗢きに

慜越, 人数相揃る迄少々見合, 五ッ時前細工始,

$\begin{array}{ll}\text { 四ッ時前（午前 10 時） } & \text { 小休 } \\ \text { 中食 } & \text { 休 } \\ \text { 八ッ時前 (午後 2 時) } & \text { 小休 }\end{array}$

朝は 6 時から 8 時頃までにというように，日が昇るとともに仕 事を始めるのが一般的だった。2 時間ごとに休秝していることか らすると, 日没に近い午後 4 時で終了だろうか。労偅時間は現代 に近い 1 日 8 時間から 10 時間ということになる。しかし，こう した規制が出されているのは, 厳しい労働条件の石屋が多かった 可能性がある。

賃金については, 元禄 13 年（1700） 9 月 25 日に, 石切たちか 高い賃金を要求してはならないという御触が出されている[市史 3-153]。仕事が多い割に石切職人の数が少ないことから, 石屋親 方に対して高貨金を要求することがあったという。

特別な仕事としては, 幕府に命じられる大坂城や江戸城などの 普請工事があった。「山村与助由緒書」によれば，家康配下の大 工だった山村与助の子孫が, 代々石切を支配している [市史 5154 。明暦 3 年 (1657) の触書では, 翌年の江戸城本丸普請に石 切職人の参加を求めている [市史 3-58]。文化 5 年 (1808) 11 月 付けの「三郷惣年寄由緒書並勤書」によると, 大坂城内の普請に 加わる石切の身元確認は, 大坂三郷 (北組・南組・天満組) の惣 年寄の仕事になっていた [市史 5-164]。幕府にとって普請のた めに職人を支配しておくことは, 戦時の備えとして必要なことだっ たらしい? 。

\section{(3) 石屋の株仲間}

江戸中期には石問屋や石工たちは利益を守るために，現在の組 合に近い形の石問屋株仲間と切石屋株仲間を結成している。石問 屋株仲間は明和 7 年 (1770) 12 月に, 冥加金として毎年金 60 両 を上納する条件で，2 軒が大坂町奉行所から許可されている[市 史 5-736・737]。石問屋仲間は建築普請に使用する石材だけを取 り扱い，燈籠・鳥居などの細工用の石は切石屋仲間が扱うという ように限定されていた［市史1-998・1109］。 
切石屋株仲間も明和 7 年 12 月に，冥加金を初めの年に丁銀 15 枚，以後は毎年丁銀 10 枚を納めることで認可されている[市史 5-737〕。石屋の株仲間としては, 石問屋以外には切石屋しかない ことからすると, 庭石屋・石塔屋あるいは石臼屋までも合わせた ものと考えられる。切石屋株からの要請によって大坂町奉行は, 明和 8 年・天明 3 年（1783）・文化 8 年（1811） - 天保元年 （1830）・天保10 年・安政 4 年（1857）に，普請手伝いの人夫た ちが切石細工をして切石屋の営業を妨害することを禁じている [市史 3-787・1004,4-535・946・1379・2208］。

文化初年 (1804) の大坂の石屋の株仲間は, 「石問屋株一軒, 切石屋株四拾六軒」だったが，嘉永 5 年（1852）には「石問屋八 人, 切石屋六拾六人」に増加している[市史 2-582・887]。

江戸では享保 6 年 (1721) 11 月に, 商人・職人に対して株仲 間の設立が認可されているが，これは幕府政策を遂行するための もので, 町奉行一町年寄一町名主という町方支配機構を通じて, 彼らを統制しようとしたとされている ${ }^{8)}$ 。しかし，大坂の石屋の 場合は冥加金を納めていることや，他の人間が類似した仕事をす ることを禁止するように強く求めていることからすると，石屋た ちが既得の権利を守るために株仲間を積極的に結成した感じが強 い。

\section{5. 地方への石造品の販売}

大坂から全国各地に石造品を販売していたことから，現在でも 各地に当時の製品が残存している。高野山にある江戸時代の大名 の墓石類の調査からは, かなりの数の大坂の石屋・石工が五輪塔・ 墓碑・鳥居・石門などを作っていることが判明している ${ }^{9)} 。$

大名からの依頼を受けて大坂で製作して販売していたわけだが， 和泉・堺・江戸などの石屋の製作品よりも圧倒的に多い。屋号・ 氏名が判明する石屋だけでも，

尼崎屋治右衛門・黒田甚兵衛・榎並屋伊兵衛正次・野田屋半 兵衛 $\cdot$ 松屋与兵衛 - 小嶋半兵衛 $\cdot$ 北野屋長右衛門 $\cdot$ 本庄屋吉 兵衛・尼崎屋友次郎・伏見堀和泉屋仁左衛門・和泉屋長兵衛 平野屋長右衛門・名田門（屋?）太郎兵衛 - 明石屋弥兵衛 伊藤屋市兵衛・樋口屋加右衛門

などがいる。高野山の墓石に近隣の地域のものよりも大坂製が多 いのは，大坂に発注すれば上質な品物が入手できたからと考えら れる。
一方, 姫路市内の石造品の調查では ${ }^{10)}$,

石工大坂 $\square \square$ 嘉兵衛（享保 7 年 [1722]供養塔）

石工大坂御影屋七兵衛（亨保 9 年鳥居）

石工大坂西横堀炭屋町みかげや新三良（寛政 6 年 [1794] 狛 犬)

石匠大坂西横堀炭屋町 御影屋新三良（寛政 6 年狛犬）

と銘が刻まれたものが, 播磨・西攝津・姫路・備前などの石造品 に混ざって発見されている。大坂に出稼ぎに行き成功した者が奉 納したのではないかと推測されているが, このような販売のされ 方もあったのだろう。

特異な例としては, 岡山藩に招かれて後楽園の流れや園池, 新 田開発のための河川の改修などを行なった大坂の石屋, 河内屋治 兵衛（岡山在住 1666〜1723）がいる。燈籠なども製作している ことからわかるように，元来は石細工が専門の石工だった ${ }^{11}$ 。

高野山の事例からすると，これまで名を挙げた石屋と同一の人 物は少なく, 江戸時代全体の大坂の石屋・石丁.は膨大な数になる と推測される。石材を燈籠・蹲踞・鳥居・五輪塔などに加工して 販売を行なっていたのは, 大坂という大都市での需要があったか らだろうが, 全国に向けて出荷したことから種類や生産数も多く なり，石工の技巧も発達したと考えられる。

\section{6. おわりに}

江戸時代には大坂に全国の物産が集められ，再び各地に販売さ れていたが，植木あその 1 つであり ${ }^{12)}$ ，石も例外ではなかった。 周辺地域の石材が集められ, 原石のまま, あるいは加工されて全 国に販売されている。

また, 大坂の石屋は, 西横堀・長堀・東横堀などの石材の運搬 に便利な河口に続く堀割り沿いに, 分布していたことが特色となっ ていた。しかし，これらの場所に現在は石屋は存在していない。 第 2 次世界大戦の空襲によって焼失したためむあったのだろうが, 石材の運搬手段が船から鉄道・自動車に変化していくにつれて, 船運に頼る必要がなくなり,これらの地域から石屋は撤退して行っ たと考えられる。

庭石の原産地，燈籠・蹲踞などの生産者や販売経路については, 大坂を調べただけでは不明な点が多いが, 石材の原産地や石造品 の販売先での調查が行なわれるようになれば，一層全体が見えて くると予測される。

\section{引用文献}

1) 奇多楼主人 (1934)：徳川期に於ける 大坂の石屋 : 上方 (38), 創元社, 4850

2 ) 大阪市史編纂所編 (1999）: 大阪市史 史料（第 53 輯）：大阪市史料調查会

3）野間光辰監修（1977）：校本難波丸綱 目: 中尾松泉堂書店

4 ) 朝倉治彦校注 (1990): 人倫訓蒙困彙 :
平凡社, $119 \cdot 156 \mathrm{pp}$.

5 ）大阪商上会議所編・発行 (1977)：大 阪経済史料集成(第 11 巻)

6 ）前掲: 大阪市史史料（第 53 輯）

7 ) 乾宏巳 (1974) : 江戸の職人：江戸町 人の研究 (第 3 巻), 吉川弘文館, 213-218pp.

8 ) 前掲: 江戸の職人, $219 \mathrm{pp}$.

9 ) 天岸正男 (1972)：奥院『石工』名集
録：史迹と美術（427号)，258-266

10）姫路市教育委員会（1995）：姫路の文 化財 石造遺品銘文集，55-60

11）柴田一（1990）: 津田永忠（下巻）：山 陽新聞社, 169-173pp.

12）飛田範夫 : 大坂の植木屋と花屋 : ラン ドスケープ研究 63(5): 日本造園学会, 357-360

Summary: In the Edo period, many garden stones, stone lanterns, tukubai (washbasins) were used at Japanese gardens. But works of stonemasons and sale routes are not made clear yet.

In Osaka stonemasons' stores located near canals to carry stones by ships. The stores mostly existed at Nishi-yokobori, Naga-hori and Higashi-yoko-bori (Matuya-machi-suji). Many kinds of excellent garden stones of other areas, and building stones produced at Mikage, Okayama and Izumi, were transported to Osaka. Those things and manufactured goods were sold to other regions, such as the graveyard of Koya-san. There are many kinds of troubles about wages, working hours, sales and so on between the stonemasons. Two guilds of stonemasons were established at 1770. One was for wholesalers and the other was for manufacturers. 